\title{
Noise Estimation Using Road and Urban Features
}

\author{
Guillermo Rey Gozalo ${ }^{1,2, * \mathbb{C}}$, Enrique Suárez ${ }^{3}$, Alexandra L. Montenegro ${ }^{3}$, Jorge P. Arenas ${ }^{3}(\mathbb{O}$, \\ Juan Miguel Barrigón Morillas ${ }^{2}(1)$ and David Montes González ${ }^{2,4}$ (i) \\ 1 Facultad de Ciencias de la Salud, Universidad Autónoma de Chile, 5 Poniente 1670, 3460000 Talca, Chile \\ 2 INTERRA, Departamento de Física Aplicada, Escuela Politécnica, Universidad de Extremadura, \\ Avda. de la Universidad s/n, 10003 Cáceres, Spain; barrigon@unex.es (J.M.B.M.); davidmg@unex.es (D.M.G.) \\ 3 Institute of Acoustics, University Austral of Chile, P.O. Box 567, 5090000 Valdivia, Chile; \\ enriquesuarez@uach.cl (E.S.); alyselottm@gmail.com (A.L.M.); jparenas@uach.cl (J.P.A.) \\ 4 ISISE, Departamento de Engenharia Civil, Universidade de Coimbra, Luis Reis dos Santos 290, \\ 3030-788 Coimbra, Portugal \\ * Correspondence: guille@unex.es; Tel.: +34-927-257-195
}

Received: 7 October 2020; Accepted: 3 November 2020; Published: 5 November 2020

\begin{abstract}
Noise pollution must be considered to achieve sustainable cities because current levels of exposure to environmental noise are a considerable risk to the health and quality of life of citizens. Urban features and sound levels were registered in 150 streets in the Chilean cities of Talca and Valdivia to analyze the relationship between both types of variables. Urban variables related to street location, urban land use, street geometry, road traffic control, and public and private transportation showed very significant correlations with the noise levels, and multiple regression models were developed from these variables for each city. Models using only urban variables in Valdivia and Talca explained $71 \%$ and $73 \%$, respectively, of the variability of noise. The prediction error was similar in the different types of urban roads and did not exhibit significant differences between models developed in different cities. The urban models developed in one city could, therefore, be used in other similar cities. Considering the usefulness of these variables in urban planning, these models can be a useful tool for urban planners and decision-makers to implement action plans regarding noise pollution.
\end{abstract}

Keywords: urban noise; environmental noise; noise measurements; urban noise planning

\section{Introduction}

International organizations have proposed indicators, requirements, objectives, and targets for sustainable development in communities [1-4]. The Reference Framework for Sustainable Cities (RFSC) defines five dimensions for a European vision of tomorrow's cities [1]. Noise pollution is considered in the environmental, spatial, and social dimensions. The European Commission developed a common set of indicators to measure their recorded progress towards sustainable local development [2]. Noise pollution was one of these indicators and was assessed through the segment of the population exposed to harmful environmental noise. The United Nations (UN) has also established a set of seventeen global goals for sustainable development by 2030 [3]. Objective 11 (sustainable cities and communities) considers the environmental problem generated by road transport. Noise is, therefore, an aspect to take into consideration for sustainable development.

Health and well-being are seen as a fundamental part of sustainable development and it is known that noise has an adverse effect on health. The European Environment Agency (EEA) recently published a report showing that environmental noise, and in particular road traffic noise, remains a major problem affecting the health and well-being of millions of people in Europe [5]. Twenty percent of Europe's population, i.e., 113 million people, are exposed to noise levels that are harmful to their health. The U.S. Environmental Protection Agency (EPA) also estimates that more than 100 million people in the United 
States are exposed annually to levels of traffic noise high enough to be harmful to health [6]. In Chile, recent studies show that noise pollution is a major environmental problem [7] that decreases the years of healthy life of its citizens [8]. Road traffic is the most impacting noise source affecting the human modern life style [9] and is then responsible for most of the health effects related to noise exposure: sleep disorders with awakenings [10,11], hypertension ischemic heart disease [12,13], mental health effects [14,15], effects on hearing systems [16,17], pregnancy outcomes and cognitive impairment in children [18,19], and especially annoyance $[20,21]$. Noise is the second largest environmental cause of health problems according to the World Health Organization (WHO) [22].

Noise not only produces harmful effects on human health, it also impacts a wide range of terrestrial and aquatic species that inhabit very different ecosystems [5]. Port activities generate high noise levels [23] and ship noise has been shown to seriously affect killer whales, whales, and dolphins [24]. Shannon et al. [25] have summarized the effects of noise on wildlife. They reported that those effects include changes in habitat use for migratory birds and estuary crabs, a decrease in the hummingbird's pollination area, alterations in predator-prey interactions on land, etc.

Environmental noise also has implications for other dimensions of society, for example for the economy: health care costs [26], accidents at work [27], lower property prices [28], etc.

In summary, the previous discussion points out the effects of environmental noise on the three dimensions of sustainable development: environmental, social, and economic. If the concept of sustainability outlined above is taken seriously, it is clear that the current level of exposure to environmental noise poses a considerable threat to the health and well-being of current and future generations in cities [29]. It is therefore important to consider noise pollution to achieve sustainable cities.

The world is becoming increasingly urbanized and $60 \%$ of the world's population is expected to live in urban areas by 2030 [3]. Rapid urbanization has resulted in inadequate and overburdened infrastructure and services, worsening noise pollution and unplanned urban sprawl. Better urban and infrastructure planning could significantly reduce the number of people exposed to harmful noise levels [5]. In addition, considering the known relationship between noise and air pollution [30], these measures could also reduce the concentration of other air pollutants, while optimizing costs and efforts. The involvement of urban planners and decision-makers in noise action plans will benefit their implementation. Citizens can also be sources of geographical information on urban features and noise levels through smartphone apps [31,32] and contribute to changing people's behavior. Cities are taking a variety of measures to address noise problems: promoting walking or cycling [33], pedestrianization of streets [34,35], increasing green spaces [36,37], etc.

Information on the relationship between noise and urban variables is useful for urban planners to assess noise and to implement action plans successfully [38]. Road traffic is the main source of noise pollution in cities $[5,39]$. Vehicles circulate the city to travel to areas of interest: shopping centers, workplaces, educational centers, etc. These routes are also influenced by the features of the road infrastructure: number of lanes, traffic lights, etc. This set of urban characteristics can provide either alternative or complementary information to that provided by road traffic variables (flow, type of vehicle, etc.). Traffic counters are generally only available on the main roads of large cities [40] and noise calculation models are implemented in expensive commercial software. However, urban variables are available in open maps (OpenStreetMap, Google Maps, etc.) or from the administrations (cadastral maps, land-use maps, etc.). Furthermore, urban features influence sound perception and therefore it is a factor to be considered in the evaluation of the soundscape [41,42]. 
The relationship between urban variables and noise levels has not gone unnoticed by the scientific community. Barrigón et al. [43] found important relationships between the city area and its average sound levels. If the functionality of the urban road was differentiated, the coefficient of determination increased significantly. Ballesteros et al. [44] proposed a procedure to predict the noise level in a leisure street knowing the number of leisure places. Currently, there is a trend in the design of the land-use regression method for the estimation of noise levels. Most of these regression models include road traffic variables, land-use, and urban road features [45,46]. Only road traffic variables (flow, type of vehicle, etc.) explain a high variability in noise levels $[47,48]$ and in this sense, current noise mapping models can be used. However, few methods employ only urban and land-use variables to estimate noise levels [49,50]. In addition, some of them do not explain the noise variability properly [50,51].

The main objective of this study is the development of models based on urban variables for estimating noise. For these purpose, urban variables and noise levels were registered on different types of urban roads and the relationship between the two variables was analyzed. These models could be an important tool for urban planners and could also help to improve the noise predictions of current noise maps. Although each city has its own features, many cities share similarities across a wide range of population sizes. In this way, the estimates obtained by urban models in two different Chilean cities were compared to analyze whether a model designed in one city can be applied to another city that has certain urban similarities.

\section{Methodology}

\subsection{Cities Studied}

This study was conducted in the cities of Talca and Valdivia. Talca is located in central Chile and has a population of about 220,000 inhabitants. Agriculture occupies a fundamental place in the economy of Talca. It is an inland city with a Mediterranean climate (dry summers and wet winters); therefore, it is hotter in summer and cooler in winter than coastal cities like Valdivia (Oceanic climate). Valdivia is a city in the southern part of Chile and has a population of about 166,000 inhabitants. Valdivia relies heavily on silviculture, the pulp and paper industry, and other forestry-related activities. Regarding the urban structure, most of the buildings are one- or two-stories with green areas in both cities. However, the center of Talca retains a gridded urban structure, unlike Valdivia. Road transport is the main means of urban and interurban communication.

\subsection{Sampling Method}

The urban street was the sampling unit. Sound measurements and urban variables were recorded in different types of streets. Urban streets were classified according to their functionality as a means of communication between different parts of the city and between the city and other urban areas (see Figure 1). The definitions proposed by the categorization method employed in previous works were used for the road classification [43,52]. It has been shown that the categorization method presents a better estimation and stratification of sound levels compared to other measurement procedures [52-54].

Because of the above, streets were not considered from an administrative point of view. Therefore, a street may have sections with different functionalities. This happens when a street is crossed by another street which supplies or subtracts a significant flow of road traffic. Consequently, these sections of the road are considered different even though they have the same name from an administrative point of view. 


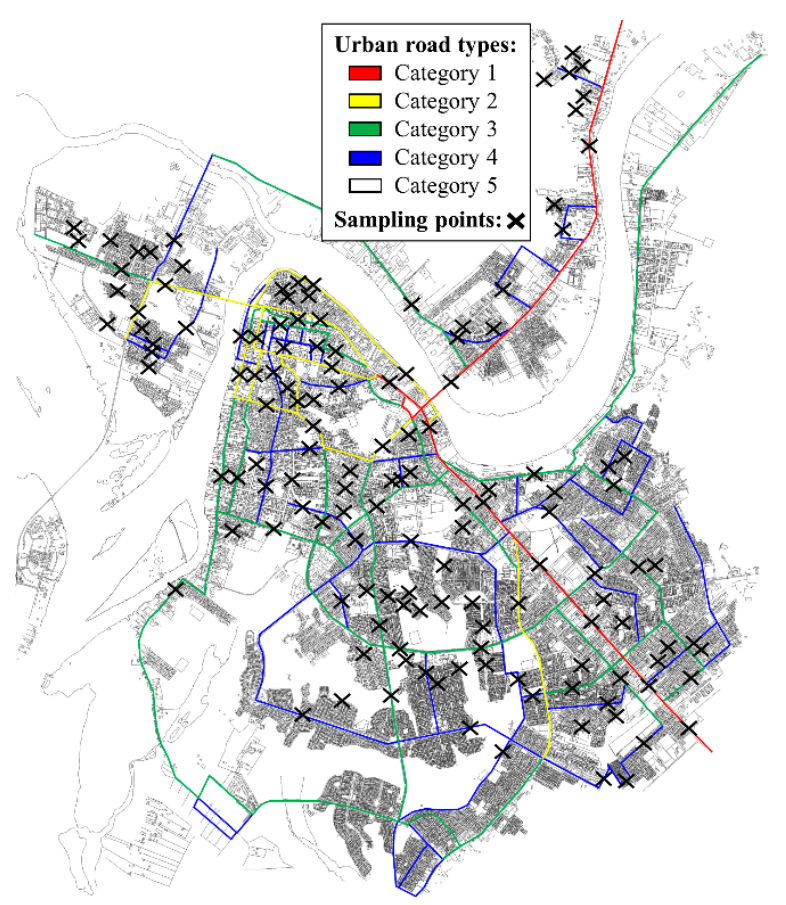

(a)

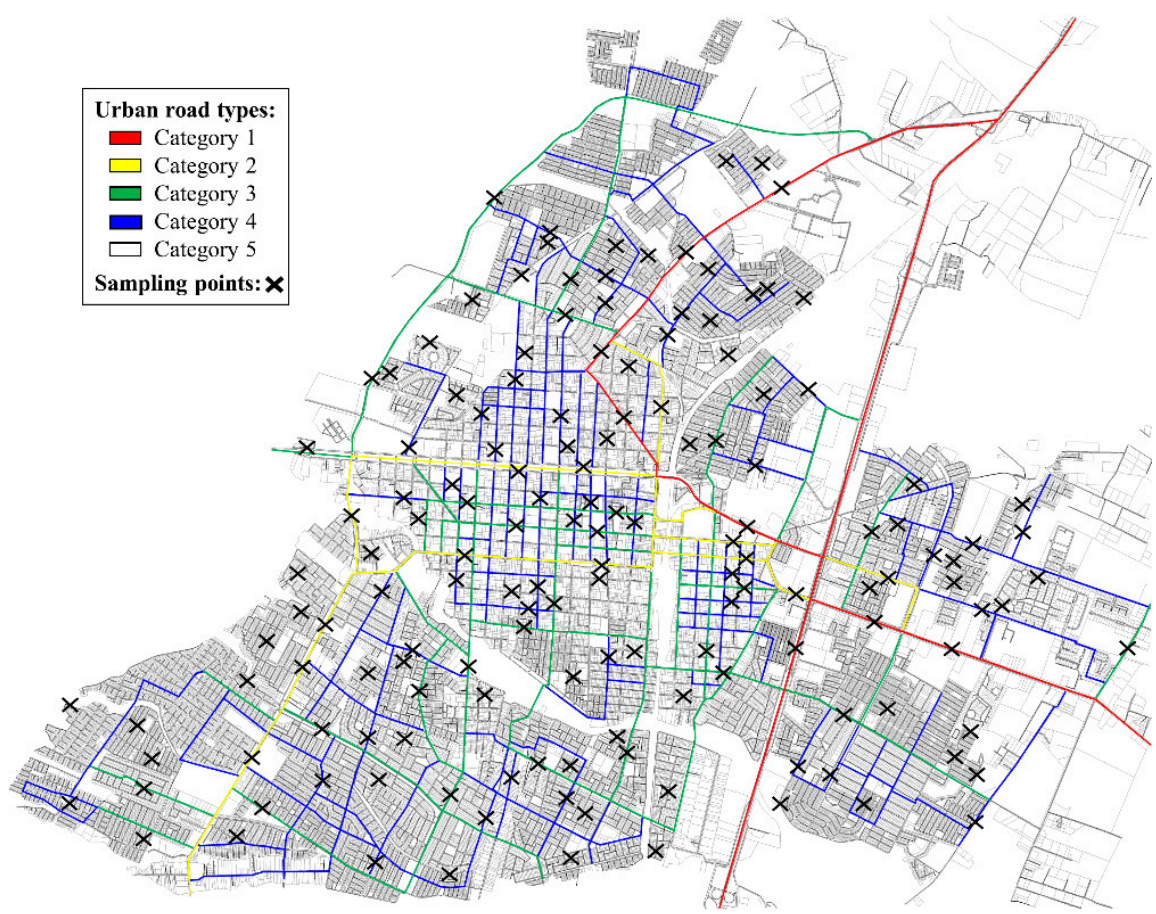

(b)

Figure 1. Sampling point locations in different road types in cities of (a) Valdivia and (b) Talca.

\subsection{Measurement Procedure}

Stratified random sampling was carried out. Initially, the streets were classified into different categories as shown in Figure 1. Then, a number of streets were randomly selected within each category. More sampling points were selected in the larger categories. A total of 151 streets were sampled in the city of Talca: 8 in category 1, 13 in category 2, 26 in category 3, 39 in category 4, and 65 in category 5. 
A similar number of streets were sampled in the city of Valdivia: 10 in category 1,14 in category 2, 23 in category 3, 36 in category 4, and 67 in category 5 for a total of 150 streets.

ISO 1996-2 guidelines were followed to carry out the sound measurements at the sampling points located in the urban streets [55]. The sound measurements were performed on different working days with a duration of $15 \mathrm{~min}$. At each sampling point, two or three measurements were taken in the diurnal period. Type-I sound level meters were used with a tripod and windshield and they were placed at a height of $1.5 \mathrm{~m}$ and away from any reflective surface. The sound level meters were calibrated before and after each measurement period. The A-weighted equivalent sound pressure level, $L_{A e q}(\mathrm{dBA})$, was used to analyze the results in the present study.

Road and urban features were registered simultaneously with the sound measurements on each street. Free sources of geographic information were used and then verified in situ. Approximately, 70 urban variables were measured on each street (see Tables 1 and 2), which could be classified in the following groups:

1. Location of the street: distance to the city center.

2. Urban land use: gyms, cinemas, pubs, restaurants, supermarkets, schools, etc.

3. Street geometry: street width, adjacent lanes, bikeway, lanes, parking, etc.

4. Road traffic control: traffic lights, crosswalks, speed bumps, etc.

5. Public and private transport: bus and taxi stops, bus routes, bus stations, etc.

Table 1. Correlations between noise level and road and urban features in Valdivia.

\begin{tabular}{|c|c|c|}
\hline$r$ Pearson & $p$-Value & Road and Urban Features \\
\hline $0.70-0.60$ & $<0.001$ & $\begin{array}{l}\text { Traffic lights (no.), crosswalks (no.), lanes (no.), } \\
\text { street length (m). }\end{array}$ \\
\hline $0.60-0.50$ & $<0.001$ & $\begin{array}{l}\text { Cafes and restaurants (no.), urban road width } \\
\text { (m), schools (no.), bus routes (no.), small shops } \\
\text { (no.), bus stops (no.), street width (m), shops (no.), } \\
\text { parking sections (no.). }\end{array}$ \\
\hline $0.50-0.40$ & $<0.001$ & $\begin{array}{l}\text { Adjacent lanes (no.), private clubs (no.), petrol } \\
\text { stations (no.), churches (no.), road signs } \\
\text { indicating places of interest (no.), floors in } \\
\text { buildings (no.), average height of buildings (m), } \\
\text { taxi stops (no.), law enforcement authorities (no.), } \\
\text { industries (no.), road signs indicating the way to } \\
\text { other cities (no.), road intersections with } \\
\text { preference (no.), fire departments (no.). }\end{array}$ \\
\hline $0.40-0.30$ & $<0.001$ & $\begin{array}{l}\text { Administrative offices (no.), police stations (no.), } \\
\text { supermarkets (no.), government officies (no.), } \\
\text { nursery schools (no.), academies (no.), health } \\
\text { centers (no.). }\end{array}$ \\
\hline $0.30-0.26$ & $<0.001$ & Hotels (no.), universities (no.), hostels (no.). \\
\hline $0.26-0.20$ & $<0.01$ & $\begin{array}{l}\text { Bus stations (no.), oncoming lanes (no.), private } \\
\text { parking (no.), pubs (no.), distance to city center } \\
\text { (m), medical clinics (no.), graveyards (no.), } \\
\text { service lanes (no.), road surface type (1-4), } \\
\text { libraries (no.). }\end{array}$ \\
\hline $0.20-0.16$ & $<0.05$ & $\begin{array}{l}\text { Malls (no.), oblique parking (no.), traffic island } \\
\text { (m), public areas (m2), bikeway (no.), sport fields } \\
\text { (no.), museums (no.), parallel parking (no.), } \\
\text { gyms (no.), road surface condition (1-3). }\end{array}$ \\
\hline$<0.16$ & $>0.05$ & $\begin{array}{l}\text { Secondary schools (no.), road intersections } \\
\text { without preference (no.), nursing homes (no.), } \\
\text { speed bumps (no.), hospitals (no.), stadiums (no.), } \\
\text { street profile, green areas (m2), road slope (0-3), } \\
\text { parking (no.), cinemas (no.), theatres (no.). }\end{array}$ \\
\hline
\end{tabular}


Table 2. Correlations between noise level and road and urban features in Talca

\begin{tabular}{|c|c|c|}
\hline$r$ Pearson & $p$-Value & Road and Urban Features \\
\hline $0.70-0.60$ & $<0.001$ & Street length (m), lines (no.), traffic lights (no.). \\
\hline $0.60-0.50$ & $<0.001$ & $\begin{array}{l}\text { Crosswalks (no.), urban road width (m), small shops } \\
\text { (no.), oncoming lanes (no.), street width (m), } \\
\text { bus stops (no.), floors in buildings (no.). }\end{array}$ \\
\hline $0.50-0.40$ & $<0.001$ & $\begin{array}{l}\text { Bus routes (no.), schools (no.), adjacent lanes (no.), } \\
\text { road surface condition (1-3), cafes and restaurants } \\
\text { (no.), road intersections with preference (no.), } \\
\text { supermarkets (no.). }\end{array}$ \\
\hline $0.40-0.30$ & $<0.001$ & $\begin{array}{l}\text { Industries (no.), shops (no.), universities (no.), } \\
\text { petrol stations (no.), gardens (no.), road signs } \\
\text { indicating the way to other cities (no.), road signs } \\
\text { indicating places of interest (no.), churches (no.), } \\
\text { medical clinics (no.). }\end{array}$ \\
\hline $0.30-0.26$ & $<0.001$ & $\begin{array}{l}\text { Law enforcement authorities (no.), police stations } \\
\text { (no.), private clubs (no.), administrative offices (no.), } \\
\text { malls (no.), secondary schools (no.), sport fields (no.). }\end{array}$ \\
\hline $0.26-0.20$ & $<0.01$ & $\begin{array}{l}\text { Government administrations (no.), average height of } \\
\text { buildings (m), pubs (no.), academies (no.), } \\
\text { speed bumps (no.), service lanes (no.), hostels (no.). }\end{array}$ \\
\hline $0.20-0.16$ & $<0.05$ & $\begin{array}{l}\text { Gyms (no.), distance to the city center (m), } \\
\text { graveyards (no.), parkings (no.), private parkings } \\
\text { (no.), parallel parking (no.), oblique parking (no.), } \\
\text { hospitals (no.). }\end{array}$ \\
\hline$<0.16$ & $>0.05$ & $\begin{array}{l}\text { Health centers (no.), fire departments (no.), } \\
\text { hotels (no.), stadiums (no.), theatres (no.), road slope } \\
(0-3) \text {, museums (no.), bus stations (no.), } \\
\text { libraries (no.), road intersections without preference } \\
\text { (no.), street profile (0-2), cinemas (no.), road surface } \\
\text { type (1-3), taxi stops (no.). }\end{array}$ \\
\hline
\end{tabular}

\subsection{Statistical Analysis}

Relationships among the urban variables and measured sound levels were analyzed. Pearson's correlation coefficient was used for this analysis. The correlation coefficient was also used to analyze the collinearity between urban variables [56]. Urban variables with a significant correlation with noise levels and without collinearity were selected for the multiple linear regression model. Stepwise multiple linear regression analysis was conducted between the sound levels and urban variables. Stepwise regression does multiple regressions several times, each time removing the weakest correlated variable using the F-test. In the end, the model includes the variables that better explain the distribution. Only urban variables with a $p$-value $<0.05$ were kept in the model. In addition, the Akaike information criterion (AIC) and the Bayesian information criterion (BIC) were considered to measure the quality of the model for a data set by balancing the model's goodness-of-fit and complexity.

Once the multiple linear regression models were obtained in each city, they were validated for normality, homoscedasticity, and linearity according to the Shapiro-Wilk, Breusch-Pagan, and Ramsey Regression Equation Specification Error (RESET) tests, respectively. In addition, the variance inflation factor (VIF) was obtained to verify the absence of multicollinearity. Finally, the predictive ability of the regression models was analyzed in both cities based on new sound measurements located in different streets of the cities (a total of 40 new sampling points). For this purpose, the prediction errors of both models were calculated and compared in each city. 


\section{Results and Discussion}

\subsection{Relationships beetween Noise and Road and Urban Features}

The sound levels recorded in the different types of road categories in both cities are shown in Figure 2. These values range from approximately $42.5 \mathrm{dBA}$ to $80.0 \mathrm{dBA}$. There is an increase in the registered sound values from category five (residential roads) to category one (main roads). Category four also includes residential streets, but these are only used as the main access to the neighborhoods. This different functionality is reflected in the registered noise. Most of the sampling points from category four showed sound levels above $65 \mathrm{dBA}$, which are known to have significant negative effects on health and quality of life [57]. Considering the daytime limit of $55 \mathrm{dBA}$ for outdoor living areas by the WHO [58], 73.3\% and $81.3 \%$ of the nearby-residents of the streets measured in Talca and Valdivia, respectively, would be exposed to noise levels that generate serious annoyance. Therefore, noise pollution is also present in these Chilean cities.

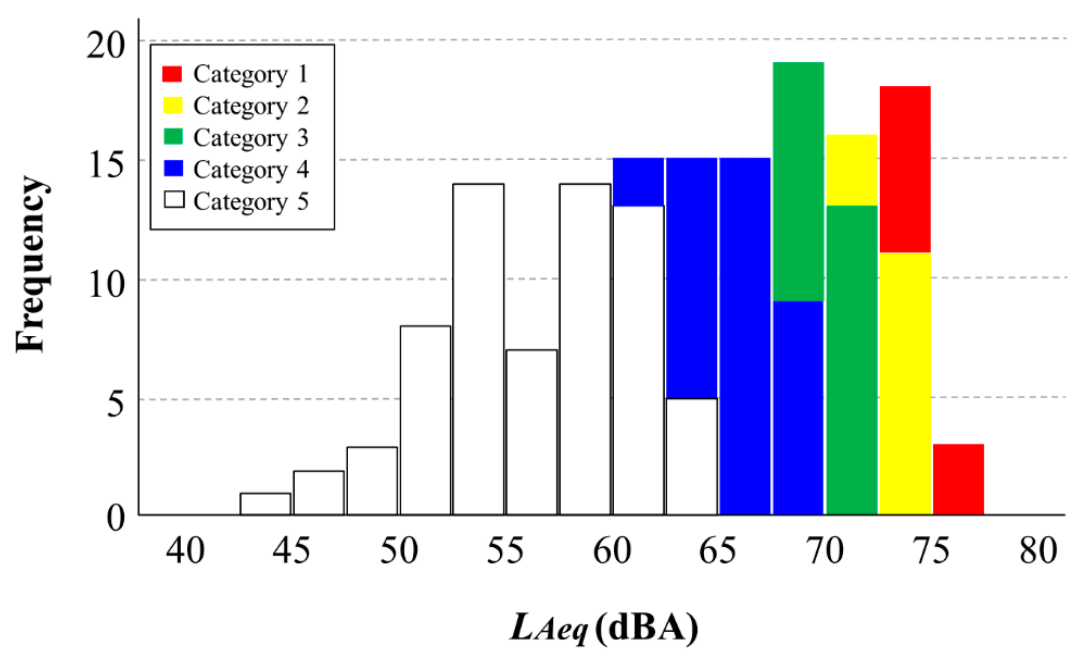

(a)

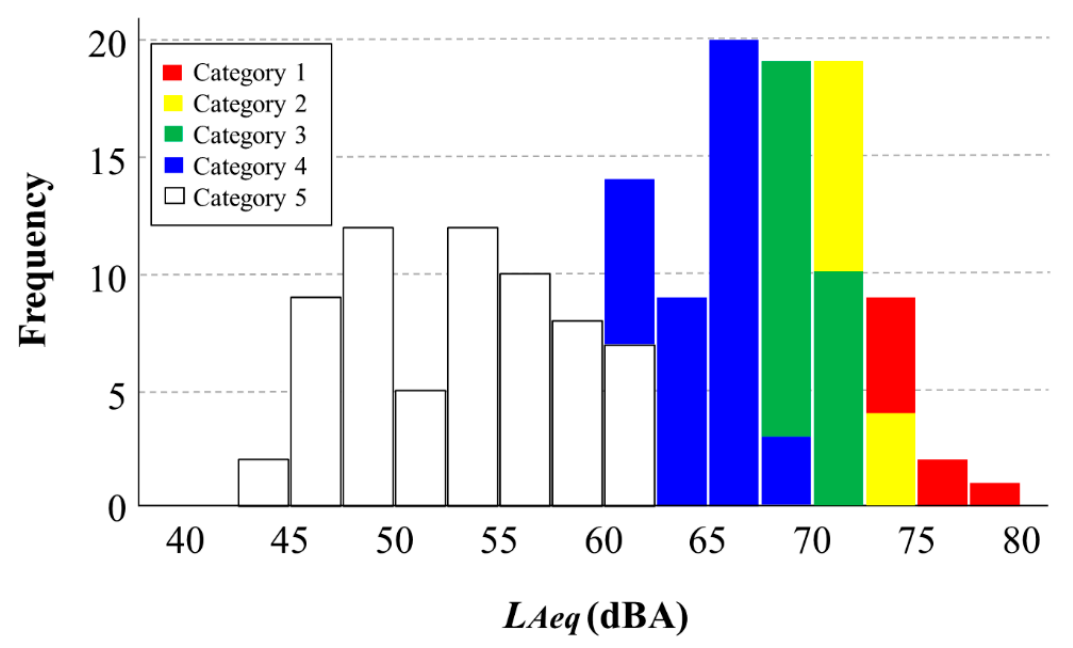

(b)

Figure 2. Histogram of sound levels registered in (a) Valdivia and (b) Talca.

The average number of some urban land uses per category is shown in Figure 3. Categories one and two have mainly the highest average number of establishments: health centers, education centers, administrative offices, shopping centers, and food and drink establishments. Category one is the main 
type of road for communication with other cities, that is, the city exit and entry roads, and category two is the main type of road within the city. The high flow of vehicles and speed in category one can limit access to certain urban land uses and therefore this category may have fewer establishments than category two. Thus, for example, establishments corresponding to health centers, educational institutions, shopping centers, and restaurants or pubs are more numerous in category two in Talca (see Figure $3 b$ ). Category three is related to service roads, that is, access roads to places of interest in the city. These roads can have a similar number of establishments as the main roads for some urban land uses (e.g., shopping centers in Valdivia and Talca).

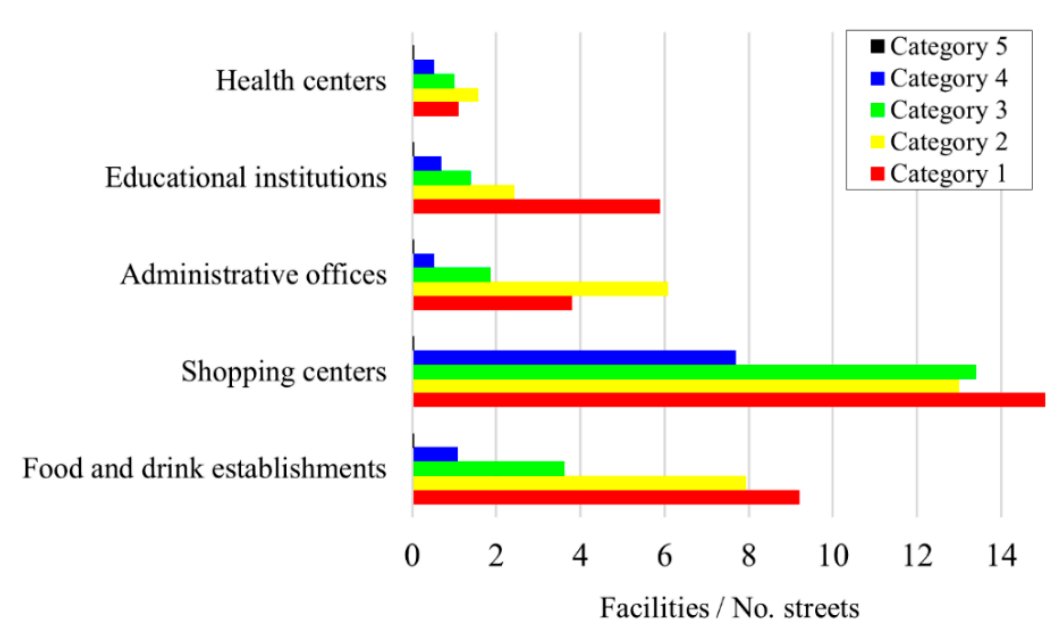

(a)

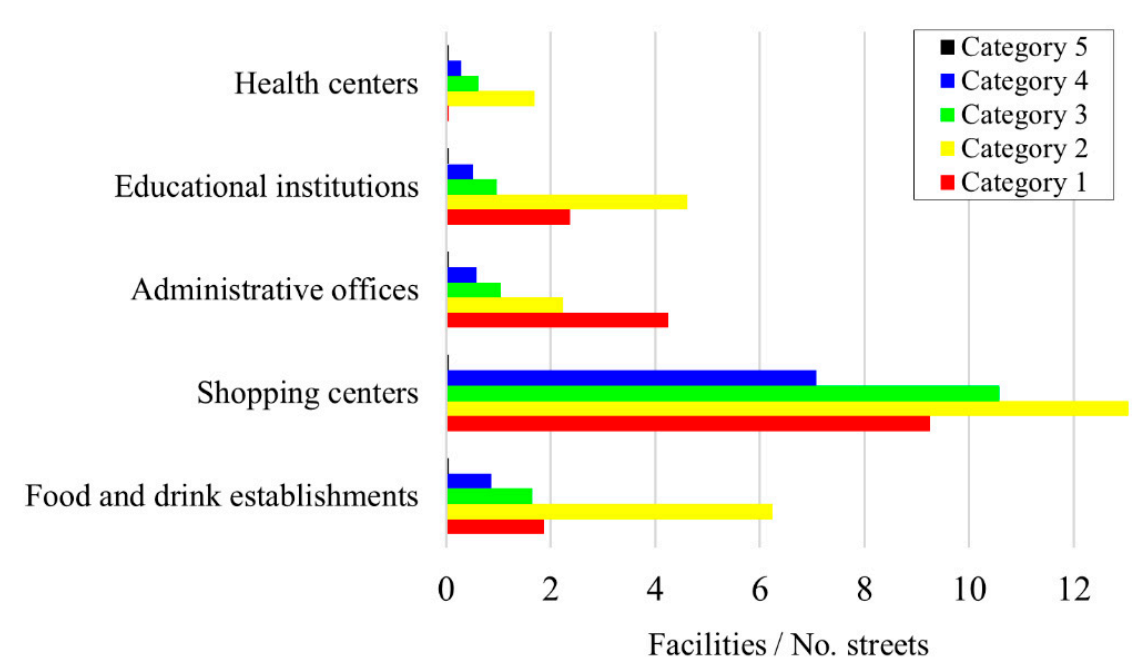

(b)

Figure 3. Distribution of some urban land uses per number of streets sampled in each category in (a) Valdivia and (b) Talca.

If Figures 2 and 3 are analyzed simultaneously, we notice that there is an increase in sound levels and the average level of establishments corresponding to different urban land uses from category five (the quietest) to category one (the noisiest). Sound levels also show an upward trend with the width of the street (see Figure 4). Therefore, the results shown in the descriptive analysis carried out in Figures 2-4, lead to the following hypothesis: there is a significant relationship between the sound level and the road and urban features recorded in the streets of Talca and Valdivia. Pearson's correlation 
coefficient $(r)$ was obtained to test this hypothesis. Tables 1 and 2 show the results of this test. Most of the urban variables analyzed have a significant correlation with the sound level ( $p$-value $<0.05)$.

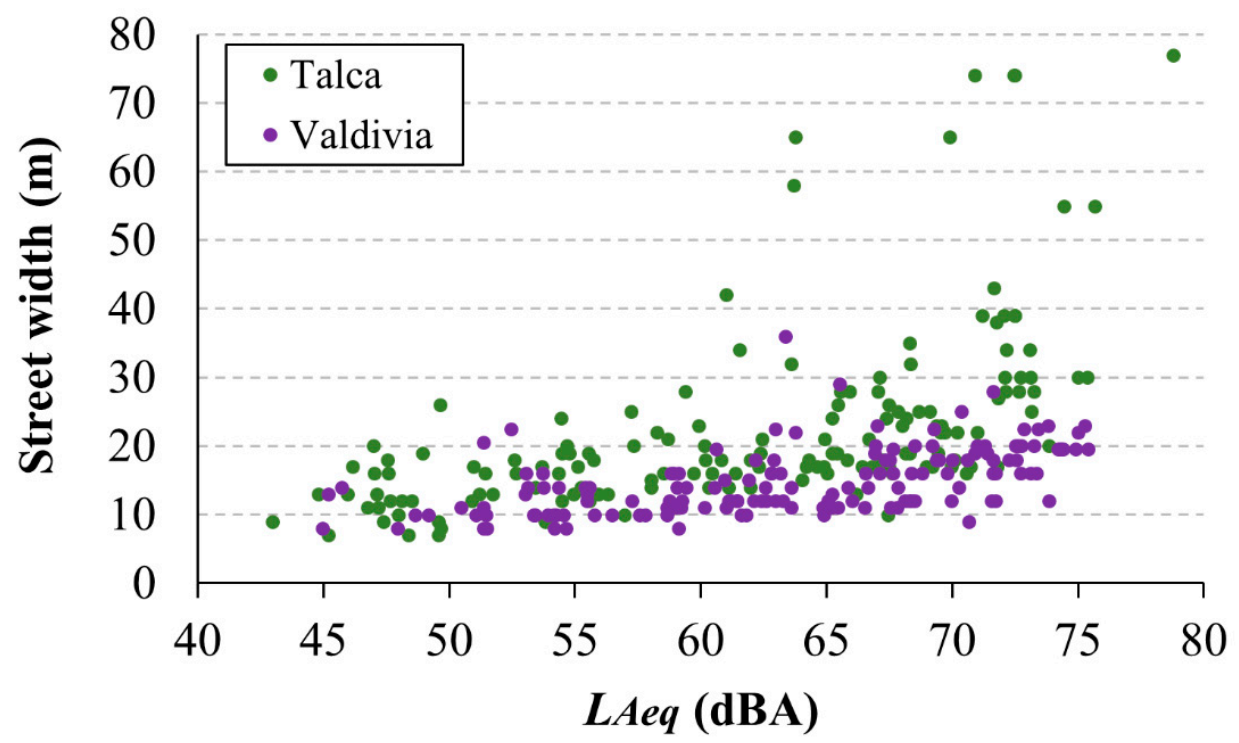

Figure 4. Relationship between equivalent sound level and street width.

Variables related to the geometry of the street exhibit $p$-values $<0.001$. The length or width of the streets are variables usually considered in noise prediction models [44-47]. The main urban streets are used to cross the city or to access areas of great interest that may be far from each other. Different types of vehicles frequently travel on these roads and, which influences their width. Medina et al. [59] have obtained correlation coefficients higher than 0.40 between the equivalent sound pressure level and street width in Ibero-American cities. Lu et al. [60] used the number of lanes as a predicting variable instead of the street width and obtained a $r=0.49$. Other variables such as road intersections, road surface, and building height have also been analyzed in previous studies but the results show correlation coefficients with less statistical significance [47,60,61].

Traffic lights and crosswalks are also urban road features included in sound prediction models [61,62]; moreover, they have shown high correlation coefficients as in the present study [61]. Traffic lights are frequent on main roads to regulate road traffic, while traffic signs are used on minor roads. Traffic lights and crosswalks are also associated with the main avenues. Pedestrian crossings also appear with speed bumps at other times.

Regarding urban land uses, the relationship between sound levels and commercial areas leads to the use of this urban variable in noise prediction models $[47,51,61]$. The presence of commercial areas exhibited a very significant correlation with the sound levels registered in the Spanish cities of Cáceres and Granada [51,61]. Industrial, business, or educational areas also show a significant relationship with noise levels, but these urban variables are less frequent than commercial areas [63].

Finally, the variables related to public and private transport should be highlighted because of their significant correlation coefficient with noise levels. Public transport is frequently used in Talca and Valdivia as well as in other cities around the world. Buses are heavy vehicles and are sometimes in poor condition. Therefore, the number of bus lanes or stops is related to an increase in noise levels. Similar results have also been shown in previous studies $[62,64,65]$. The presence of parking is another urban variable to be considered. Montes González et al. [66] have reported the effects of parking lots on sound exposure levels.

Considering this large set of urban variables that present a significant correlation with noise, urban noise prediction models could be created by using multivariate analysis. This hypothesis is analyzed in the following section of this article. 


\subsection{Urban Features Model}

Tables 3 and 4 show the selected urban variables (independent variables) in a multiple regression analysis in Talca and Valdivia where $L_{A e q}(\mathrm{dBA})$ was the dependent variable.

Table 3. Regression model using road and urban features in Valdivia.

\begin{tabular}{lllll}
\hline \multicolumn{1}{c}{ Variables } & Coefficient & Std. Error & $t$-Value & $p$-Value \\
\hline (Intercept) & 43.32 & 2.04 & 21.22 & $<0.001$ \\
Traffic lights & 1.28 & 0.39 & 3.24 & $<0.01$ \\
Crosswalks & 0.83 & 0.27 & 3.08 & $<0.01$ \\
Road surface condition & 2.51 & 0.77 & 3.28 & $<0.01$ \\
Lanes & 1.60 & 0.52 & 3.05 & $<0.01$ \\
Law enforcement authorities & -4.76 & 1.13 & -4.23 & $<0.001$ \\
Bus routes & 1.01 & 0.20 & 5.11 & $<0.001$ \\
Schools & 2.69 & 1.01 & 2.68 & $<0.01$ \\
Floors in buildings & 2.19 & 0.64 & 3.43 & $<0.001$ \\
Street length & 0.006 & 0.001 & 4.57 & $<0.001$ \\
Bus stops & -0.64 & 0.19 & -3.38 & $<0.001$ \\
Shops & -0.14 & 0.06 & -2.46 & $<0.05$ \\
\hline Goodness-of-fit & & & & \\
\hline F-statistic & 31.22 & & & \\
AIC & 873.93 & & & \\
BIC & 913.07 & & & \\
Multiple $R^{2}$ & 0.71 & & & \\
Adjusted $R^{2}$ & 0.70 & & & \\
Mean absolute error & 3.20 & & & \\
\hline
\end{tabular}

Table 4. Regression model using road and urban features in Talca

\begin{tabular}{lllll}
\hline Variables & Coefficient & Std. Error & $t$-Value & $p$-Value \\
\hline (Intercept) & 42.15 & 2.00 & 21.05 & $<0.001$ \\
Street length & 0.007 & 0.001 & 6.08 & $<0.001$ \\
Road signs indicating places of interest & -3.30 & 0.66 & -5.02 & $<0.001$ \\
Parallel parking & 7.52 & 1.26 & 5.95 & $<0.001$ \\
Road surface condition & 3.21 & 0.71 & 4.53 & $<0.001$ \\
Small shops & 0.73 & 0.17 & 4.37 & $<0.001$ \\
Law enforcement authorities & -7.98 & 1.50 & -5.31 & $<0.001$ \\
Speed bumps & 2.08 & 0.85 & 2.45 & $<0.05$ \\
Floors in buildings & 2.74 & 0.98 & 2.79 & $<0.01$ \\
Street width & 0.12 & 0.03 & 4.24 & $<0.001$ \\
Shops & 0.17 & 0.04 & 3.96 & $<0.001$ \\
\hline Goodness-of-fit & & & & \\
\hline F-statistic & 38.58 & & & $<0.001$ \\
AIC & 909.47 & & & \\
BIC & 945.67 & & & \\
Multiple $R^{2}$ & 0.73 & & & \\
Adjusted $R^{2}$ & 0.72 & & & \\
Mean absolute error & 3.65 & & & \\
\hline
\end{tabular}

The trade-off between the model's goodness-of-fit and its simplicity was the objective in the selection of urban variables in the multivariate model. Because of this, a stepwise regression was used (Tables 3 and 4). The following goodness-of-fit parameters would be obtained in models composed of all urban variables registered in both cities (Tables 1 and 2):

- $\quad$ AIC: 908.36 (Valdivia), 920.22 (Talca).

- $\quad$ BIC: 1116.10 (Valdivia), 1098.24 (Talca).

- $\quad$ Multiple $R^{2}: 0.83$ (Valdivia), 0.85 (Talca).

- $\quad$ Adjusted $R^{2}: 0.69$ (Valdivia), 0.73 (Talca). 
The multiple determination coefficients (multiple $R^{2}$ ) obtained for the models composed of approximately 70 urban variables are higher than those obtained in Tables 3 and 4 . However, these models would be very complex because they have too many variables. If the inclusion of non-significant explicative variables is penalized (adjusted $R^{2}$ ), the regression models show a determination coefficient similar to that obtained for the total number of urban variables. In addition, these models present seven times fewer independent variables, as shown in Tables 3 and 4.

The final regression models obtained in Valdivia and Talca (Tables 3 and 4) were validated for normality, homoscedasticity, and linearity. In addition, road and urban features selected in the models had a VIF value $<5$ indicating non-multicollinearity between them [67].

Variables related to street geometry and urban land use were the most abundant in both models (see Tables 3 and 4): road surface condition, lanes, street width, street length, floors in buildings, law enforcement authorities, shops, and small shops. This typology of urban variables has also been selected in previous studies as a predictor of sound levels in urban models [44,49,51]. In addition, models that include urban variables, variables related to road traffic (flow, number of vehicles, etc.), and variables related to the geometry of the street significantly increase the accuracy in the prediction of sound levels $[46,47]$. Pavement ageing, texture and mixture influence the emission of sound levels. New pavements and rubberized asphalts have been demonstrated to mitigate noise emissions [68-70].

Traffic lights and crosswalks have a highly significant influence on the sound values recorded in Valdivia. Considering these types of variables, speed bumps and road signs indicating places of interest were included as predicting variables in Talca's model. Hourovi et al. [62] also included the traffic light variable in their noise model for the city of Beer-Sheva (Israel).

Regarding urban land uses, schools, shops, and law enforcement authorities are variables within the generated models. It is interesting to note that law enforcement authorities (firefighters, police, etc.) are most often found on main roads, enabling them to rapidly reach different areas in the city. Fire emergencies are common in Chilean cities in winter.

Public transport, mainly urban buses, is frequently used in Chilean cities as indicated above. The regression model obtained in Valdivia includes the bus route and bus stop variables.

The variability explained by the regression models is $71 \%$ and $73 \%$ in Valdivia and Talca, respectively. Sieber et al. [51] obtained an adjusted $R^{2}=0.13$ in a model composed of only urban variables in Cape Town, suggesting analysis of the influence of other urban variables. Using variables related to the spatial concentration of the population and commercial activities, Yang et al. [50] developed regression models exhibiting a determination coefficient of 0.44 . The traffic noise model obtained by Oiamo et al. [49] had an $R^{2}$ of 0.58 for the daytime period. This noise model, when corrected for other noise sources, increased the percentage of variability explained to $64 \%$. Therefore, the results obtained in the present study show that registration of different types of road and urban features could benefit an improvement of the precision of the noise models composed of only urban variables.

In addition, the estimation of urban noise by the models shown in Tables 3 and 4 is comparable to those models that use road traffic variables (flow, type of vehicles, etc.). Aguilera et al. [46] obtained determination coefficients of 0.70 and 0.73 in the cities of Basel (Switzerland) and Grenoble (France), respectively. Hourovi et al. [62] also included traffic flow in the regression model developed in the city of Beer-Sheva (Israel) and the $R^{2}$ was 0.52 . Lu et al. [60] analyzed the influence of urban road characteristics on traffic noise and the resulting model variance was between $54 \%$ and $56 \%$. The model performance (adjusted $R^{2}$ ) developed by Ragettli et al. in Montreal (Canada) was 0.68 for $L_{\text {Aeq2 } 4 h}$ [64].

Both models contain some similar urban features: shops, road surface condition, law enforcement authorities, street length, and floors in buildings. Other features also have similar correlation coefficients as shown in Tables 1 and 2. Therefore, the next hypothesis proposed was that both models could be used to estimate noise in both cities. For this purpose, 40 new streets were sampled in each city and the performance of both models was analyzed. The results are shown in the next section. 


\subsection{Noise Estimation in Different Types of Road Categories}

Figures 5 and 6 show the absolute prediction errors ( $\mid L_{\text {Aeq }}$ measured $-L_{A e q}$ estimated $\left.\mid\right)$ of both models in both cities. Therefore, each model was also analyzed in the city in which it was not developed.

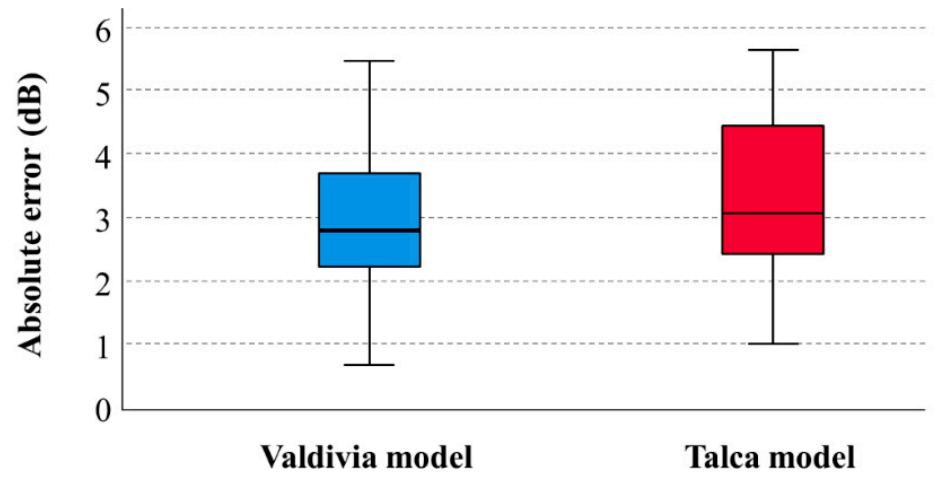

(a)

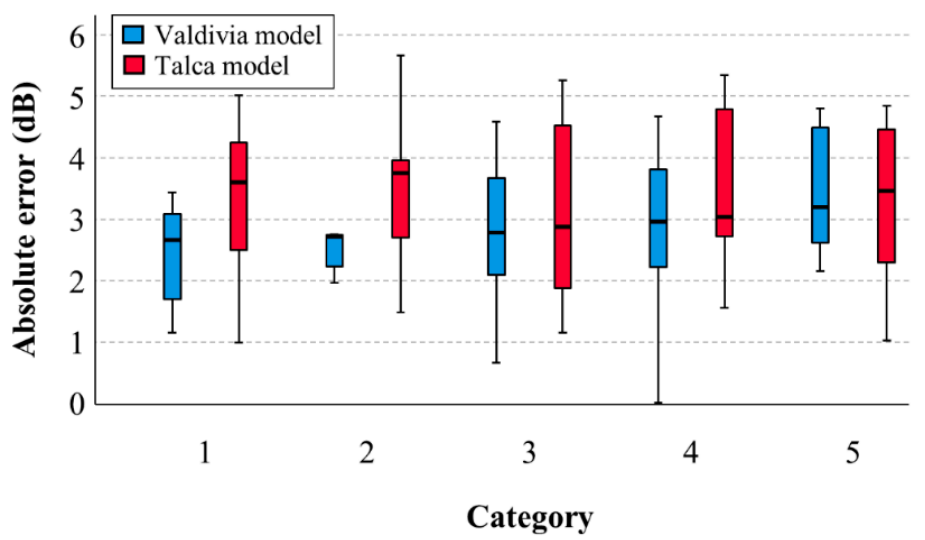

(b)

Figure 5. Box plots representing the absolute errors of the sound levels estimated by the regression models in (a) the total of sampled points in Valdivia and (b) differentiating for each type of urban road.

A total of 40 streets were sampled for this analysis in each city as indicated above and these were distributed in the different categories as follows: 5 in category 1, 5 in category 2,10 in category 3,10 in category 4 , and 10 in category 5 .

The absolute error of the model developed in that city is lower than the error of the model developed in the other city. A priori, this result was expected. However, these median values are not significantly low, as shown in Table 5. Consequently, models created in one city could be applied in other similar cities.

The median of the absolute prediction errors is close to $3 \mathrm{~dB}$ and most of the errors are lower than $5 \mathrm{dBA}$. The Good Practice Guide for Strategic Noise Mapping recommends that the noise model uncertainties should not exceed $5 \mathrm{~dB}$ [71]. Both regression models only exceeded the $5 \mathrm{~dB}$ error at one sampling point in Talca (see Figure 6). A similar result was obtained in Valdivia except for Talca's regression model where five sampling points obtained an error close to $5 \mathrm{dBA}$ (see Figure 5). Even an error limit of $4 \mathrm{~dB}$ is allowed, high percentages are below this value: $85 \%$ for the regression models developed in that city and about $70 \%$ for the regression models developed in the other city. 


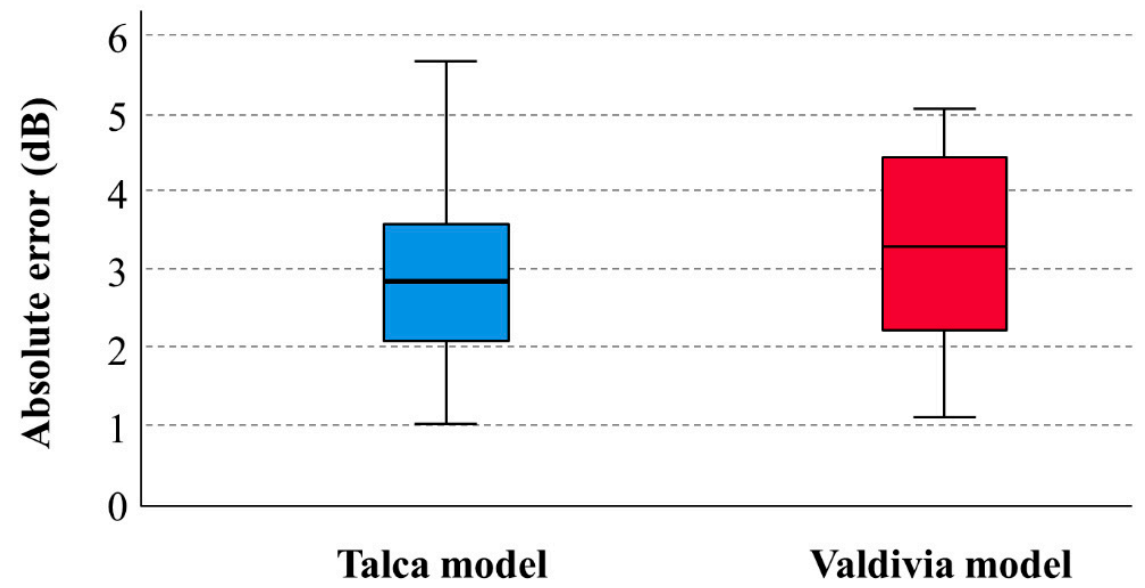

(a)

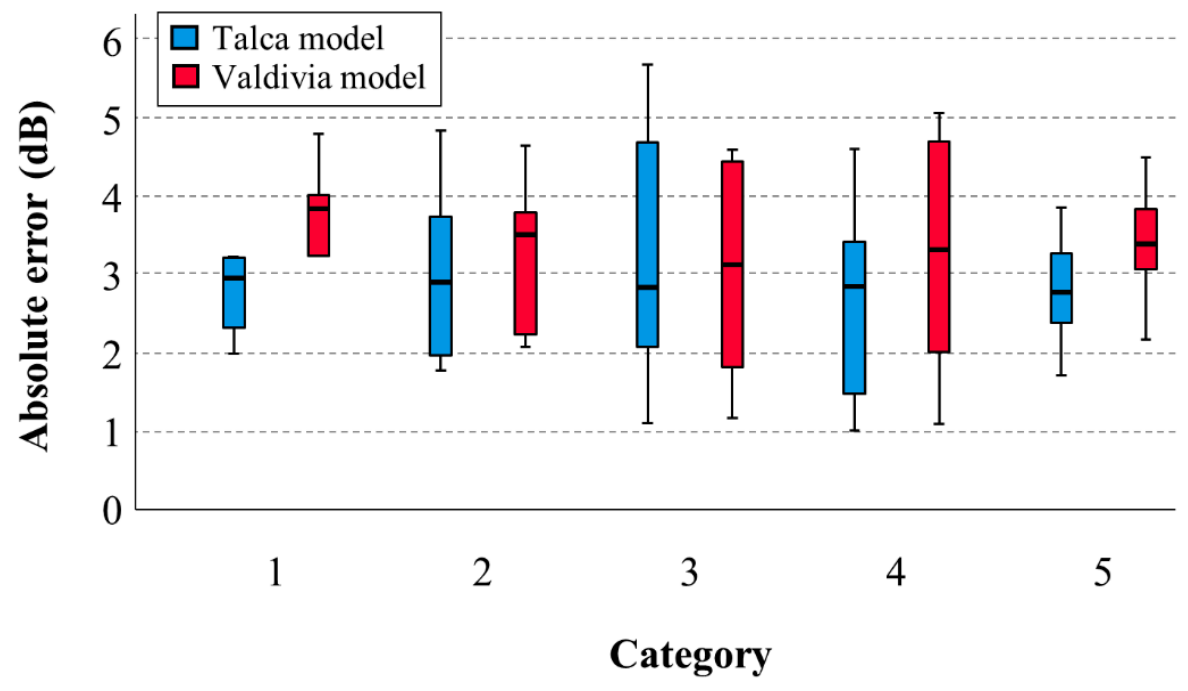

(b)

Figure 6. Box plots representing the absolute errors of the sound levels estimated by the regression models in (a) the total of sampled points in Talca and (b) differentiating for each type of urban road.

Table 5. $p$-Values obtained by comparing the absolute errors of both regression models in each city using the Mann-Whitney $U$ test.

\begin{tabular}{lcc}
\hline & Valdivia & Talca \\
\cline { 2 - 3 } Total points & 0.21 & 0.20 \\
Category 1 & 0.42 & 0.42 \\
Category 2 & 0.60 & 0.69 \\
Category 3 & 0.80 & 0.68 \\
Category 4 & 0.39 & 0.31 \\
Category 5 & 0.84 & 0.16 \\
\hline
\end{tabular}

The absolute errors are similar between the different road categories in both cities. Models developed in the city itself tend to exhibit a higher error on residential roads while models developed in another city show a higher error on main roads (see Figures 5 and 6). However, there are no significant differences between the median values of the different categories ( $p$-value $>0.05$ using the Mann-Whitney $U$ test). 
It is interesting to obtain a model whose precision is similar in the different typologies of urban roads. Noise estimates are generally more uncertain in residential roads $[39,43,72]$. This greater uncertainty is also associated with less knowledge of the urban variables and features of these roads [40]. The highest percentage of citizens live on residential roads and, therefore, an accurate prediction of sound levels on these streets is also important.

The average relative error of the estimates of both models in both cities is close to zero. In Talca, the average value of the relative error of the model developed in this city is 0.28 and 1.09 for the model developed in Valdivia. In Valdivia, the average value of the relative error of the model developed in this city is 0.24 , and it is 0.51 for the model developed in Talca. Thus, the distribution of prediction errors is unbiased.

Considering the results obtained for the developed models, they can be an alternative or a complement to the current methods of urban noise prediction. Urban variables are characteristics to be considered in urban planning and, therefore, these models can provide important information for future action plans regarding noise pollution.

\section{Conclusions}

A study of urban and noise variables was carried out in the cities of Valdivia and Talca (Chile) to analyze the relationships between these variables and to be able to develop urban models for the prediction of noise levels. The main conclusions drawn from the results are the following:

- A total of $73.3 \%$ and $81.3 \%$ of the streets measured in Talca and Valdivia, respectively, exceed the daytime sound level of $55 \mathrm{~dB}$, generating a serious potential annoyance for the citizens. Therefore, noise pollution is also present in the cities of Chile and should be considered in actions aimed at sustainability.

- Urban variables related to street location, urban land use, street geometry, road traffic control and public and private transport were shown to be highly correlated with noise levels. Considering the usefulness of these variables in urban planning, they could be used in noise prediction models.

- Multiple regression models were developed in Valdivia and Talca using only urban variables for noise prediction. The models developed in Valdivia $\left(L_{\text {Aeq }}=43.32+1.28\right.$ traffic lights +0.83 crosswalks +2.51 road surface condition +1.60 lanes -4.76 law enforcement authorities +1.01 bus routes +2.69 schools +2.19 floors in buildings +0.006 street length -0.64 bus stops -0.14 shops) and Talca $\left(L_{\text {Aeq }}=42.15+0.007\right.$ street length -3.30 road signs indicating places of interest +7.52 parallel parking +3.21 road surface condition +0.73 small shops -7.98 law enforcement authorities +2.08 speed bumps +2.74 floors in buildings +0.12 street width +0.17 shops) were able to explain the urban noise variability by $71 \%$ and $73 \%$, respectively. These models can be a useful tool for urban planners to implement action plans regarding noise pollution.

- The median of the absolute errors in the noise estimation using the models developed in both Chilean cities was approximately $3 \mathrm{dBA}$. Urban models did not present significant differences in their uncertainties despite being in a different city from that in which the model was developed. Therefore, urban models created in one city could be applied in other similar cities.

- Comparable errors were obtained in the different types of urban roads. In addition, the errors were not biased. Thus, these models can be either an alternative or a complement for noise prediction, especially in streets where there is no precise register of the sound sources.

Author Contributions: Conceptualization, G.R.G. and J.M.B.M.; methodology, G.R.G.; software, G.R.G.; validation, G.R.G.; formal analysis, G.R.G.; investigation, G.R.G., E.S., A.L.M., J.P.A., J.M.B.M. and D.M.G.; resources, G.R.G., E.S. and J.P.A.; data curation, G.R.G. and A.L.M.; writing-original draft preparation, G.R.G.; writing-review and editing, G.R.G., E.S., J.P.A., J.M.B.M. and D.M.G.; visualization, G.R.G.; supervision, G.R.G., E.S., A.L.M., J.P.A., J.M.B.M. and D.M.G.; project administration, G.R.G.; project acquisition, G.R.G., E.S. and J.P.A. All authors have read and agreed to the published version of the manuscript. 
Funding: This research was funded by Chilean National Commission for Scientific and Technological Research (CONICYT), now called National Agency for Research and Development (ANID), through the project FONDECYT No. 1180547.

Acknowledgments: G.R.G. thanks the Consejería de Economía, Ciencia y Agenda Digital of Junta de Extremadura for the grant for attracting and returning research talent to R\&D\&I centres belonging to the Extremadura Science, Technology and Innovation System (TA18019) and D.M.G. thanks the Consejería de Economía, Ciencia y Agenda Digital of Junta de Extremadura, European Union and European Social Fund (ESF) for the grant for the strengthening of R\&D\&I through the mobility of postdoctoral researchers (PO17014), where University of Extremadura was the beneficiary entity in both cases.

Conflicts of Interest: The authors declare no conflict of interest.

\section{References}

1. The Reference Framework for Sustainable Cities. 5 Dimensions and 30 Objectives for a European Vision of Tomorrow's Cities; RFSC: Luxembourg, 2016. Available online: http://rfsc.eu/ (accessed on 27 August 2020).

2. European Commission. Towards a Local Sustainability Profile: European Common Indicators; Office for Official Publications of the European Communities: Luxembourg, 2000. Available online: https://op.europa.eu/en/ publication-detail/-/publication/33eba485-e1e3-4748-9358-0d66ef86bcc3 (accessed on 27 August 2020).

3. United Nations. Transforming our World: The 2030 Agenda for Sustainable Development; UN: A/RES/70/1. 2015. Available online: https://www.un.org/sustainabledevelopment (accessed on 27 August 2020).

4. ISO 37101. Sustainable Development in Communities_Management System for Sustainable Development-Requirements with Guidance for Use; International Organization for Standardization: Geneva, Switzerland, 2016.

5. European Environment Agency. Environmental Noise in Europe-2020; Publications Office of the European Union: Luxembourg, 2020.

6. Hammer, M.S.; Swinburn, T.K.; Neitzel, R.L. Environmental Noise Pollution in the United States: Developing an Effective Public Health Response. Environ. Health Persp. 2014, 12, 115-119. [CrossRef]

7. Dirección de Estudios Sociales del Instituto de Sociología de la Pontificia Universidad Católica de Chile. Informe Final_Encuesta Nacional de Medio Ambiente 2018; Licitación No608897-110-LE17; Ministerio de Medio Ambiente: Santiago, Chile, 2018. Available online: https://mma.gob.cl/wp-content/uploads/2018/03/InformeFinal-Encuesta-Nacional-de-Medio-Ambiente-2018.pdf (accessed on 27 August 2020).

8. Gómez, I.; Glisser, M.; Padilla, C. Influence of road traffic noise in ischaemic heart disease. Introduction to the issue in Santiago of Chile. In Proceedings of the 44th International Congress and Exposition on Noise Control Engineering, INTER-NOISE 2015, San Francisco, CA, USA, 9-12 August 2015.

9. Ruiz-Padillo, A.; Ruiz, D.P.; Torija, A.J.; Ramos-Ridao, Á. Selection of suitable alternatives to reduce the environmental impact of road traffic noise using a fuzzy multi-criteria decision model. Environ. Impact Assess. 2016, 61, 8-18. [CrossRef]

10. Muzet, A. Environmental noise, sleep and health. Sleep Med. Rev. 2007, 11, 135-142. [CrossRef]

11. Park, T.; Kim, M.; Jang, C.; Choung, T.; Sim, K.-A.; Seo, D.; Chang, S. The Public Health Impact of Road-Traffic Noise in a Highly-Populated City, Republic of Korea: Annoyance and Sleep Disturbance. Sustainability 2018, 10, 2947. [CrossRef]

12. Dratva, J.; Phuleria, H.C.; Foraster, M.; Gaspoz, J.-M.; Keidel, D.; Künzli, N.; Sally Liu, L.-J.; Pons, M.; Zemp, E.; Gerbase, M.W.; et al. Transportation Noise and Blood Pressure in a Population-Based Sample of Adults. Environ. Health Persp. 2011, 120, 50-55. [CrossRef]

13. Babisch, W.; Beule, B.; Schust, M.; Kersten, N.; Ising, H. Traffic noise and risk of myocardial infarction. Epidemiology 2005, 16, 33-40. [CrossRef] [PubMed]

14. Mehri, A.; Alimohammadi, I.; Ebrahimi, H.; Hajizadeh, R.; Roudbari, M. Effect of traffic noise on mental performance with regard to introversion and task complexity. Appl. Acoust. 2018, 132, 118-123. [CrossRef]

15. Ma, J.; Li, C.; Kwan, M.-P.; Kou, L.; Chai, Y. Assessing personal noise exposure and its relationship with mental health in Beijing based on individuals' space-time behavior. Environ. Int. 2020, 139, 105737. [CrossRef] [PubMed]

16. Tandel, B.N.; Macwan, J.E.M. Road traffic noise exposure and hearing impairment among traffic policemen in Surat, Western India. J. Inst. Eng. Ser. A 2017, 98, 101-105. [CrossRef] 
17. Nagodawithana, N.S.; Pathmeswaran, A.; Pannila, A.S.; Wickramasinghe, A.R.; Sathiakumar, N. Noise-induced hearing loss among traffic policemen in the city of Colombo, Sri Lanka. Asian J. Water Environ. Pollut. 2015, 120, 9-14. [CrossRef]

18. Dzhambov, A.M.; Dimitrova, D.D.; Dimitrakova, E.D. Noise exposure during pregnancy, birth outcomes and fetal development: Meta-Analyses using quality effects model. Folia Medica 2014, 56, 204-214. [CrossRef]

19. Brown, A.; van Kamp, I. WHO Environmental Noise Guidelines for the European Region: A Systematic Review of Transport Noise Interventions and Their Impacts on Health. Int. J. Environ. Res. Public Health 2017, 14, 873. [CrossRef]

20. Miedema, H.M.E.; Oudshoorn, C.G.M. Annoyance from transportation noise: Relationships with exposure metrics DNL and DENL and their confidence intervals. Environ. Health Perspect. 2001, 109, 409-416. [CrossRef]

21. Alves, J.; Silva, L.; Remoaldo, P. The Influence of Low-Frequency Noise Pollution on the Quality of Life and Place in Sustainable Cities: A Case Study from Northern Portugal. Sustainability 2015, 7, 13920-13946. [CrossRef]

22. World Health Organization. Burden of Disease from Environmental Noise-Quantification of Healthy Life Years Lost in Europe; WHO Regional Office for Europe: Copenhagen, Denmark, 2011. Available online: https://apps.who.int/iris/handle/10665/326424 (accessed on 29 August 2020).

23. Fredianelli, L.; Nastasi, M.; Bernardini, M.; Fidecaro, F.; Licitra, G. Pass-by Characterization of Noise Emitted by Different Categories of Seagoing Ships in Ports. Sustainability 2020, 12, 1740. [CrossRef]

24. Veirs, S.; Veirs, V.; Wood, J.D. Ship noise extends to frequencies used for echolocation by endangered killer whales. PeerJ 2016, 4, e1657. [CrossRef]

25. Shannon, G.; McKenna, M.F.; Angeloni, L.M.; Crooks, K.R.; Fristrup, K.M.; Brown, E.; Warner, K.A.; Nelson, M.D.; White, C.; Briggs, J.; et al. A synthesis of two decades of research documenting the effects of noise on wildlife. Biol. Rev. 2015, 91, 982-1005. [CrossRef]

26. Tobías, A.; Díaz, J.; Sáez, M.; Alberdi, J.C. Use of Poisson regression and Box-Jenkins models to evaluate the short-term effects of environmental noise levels on daily emergency admissions in Madrid, Spain. Eur. J. Epidemiol. 2001, 17, 765-771. [CrossRef]

27. Picard, M.; Girard, S.A.; Simard, M.; Larocque, R.; Leroux, T.; Turcotte, F. Association of work-related accidents with noise exposure in the workplace and noise-induced hearing loss based on the experience of some 240,000 person-years of observation. Accident Anal. Prev. 2008, 40, 1644-1652. [CrossRef]

28. Szczepańska, A.; Senetra, A.; Wasilewicz-Pszczółkowska, M. The Influence of Traffic Noise on Apartment Prices on the Example of a European Urban Agglomeration. Sustainability 2020, 12, 801. [CrossRef]

29. Murphy, E.; King, E.A. Mapping for sustainability: Environmental noise and the city. In Methods of Sustainability Research in the Social Sciences; Fahy, F., Rau, H., Eds.; SAGE Publications: London, UK, 2013; p. 133. [CrossRef]

30. Jeon, J.; Hong, J.; Kim, S.; Kim, K.-H. Noise Indicators for Size Distributions of Airborne Particles and Traffic Activities in Urban Areas. Sustainability 2018, 10, 4599. [CrossRef]

31. Aumond, P.; Can, A.; Rey Gozalo, G.; Fortin, N.; Suárez, E. Method for in situ acoustic calibration of smartphone-based sound measurement applications. Appl. Acoust. 2020, 166, 107337. [CrossRef]

32. Devkota, B.; Miyazaki, H.; Witayangkurn, A.; Kim, S.M. Using Volunteered Geographic Information and Nighttime Light Remote Sensing Data to Identify Tourism Areas of Interest. Sustainability 2019, 11, 4718. [CrossRef]

33. Axsen, J.; Sovacool, B.K. The roles of users in electric, shared and automated mobility transitions. Transp. Res. D Transp. Environ. 2019, 71, 1-21. [CrossRef]

34. Gómez Escobar, V.; Barrigón Morillas, J.M.; Rey Gozalo, G.; Vaquero, J.; Méndez Sierra, J.A.; Vílchez-Gómez, R.; Carmona del Río, F.J. Acoustical environmental of the medieval centre of Cáceres (Spain). Appl. Acoust. 2012, 73, 673-685. [CrossRef]

35. Barrigón Morillas, J.M.; Gómez Escobar, V.; Rey Gozalo, G. Noise source analyses in the acoustical environment of the medieval centre of Cáceres (Spain). Appl. Acoust. 2013, 74, 526-534. [CrossRef]

36. Ferrini, F.; Fini, A.; Mori, J.; Gori, A. Role of Vegetation as a Mitigating Factor in the Urban Context. Sustainability 2020, 12, 4247. [CrossRef]

37. Rey Gozalo, G.; Barrigón Morillas, J.M.; Montes González, D. Perceptions and use of urban green spaces on the basis of size. Urban For. Urban Green. 2019, 46, 126470. [CrossRef] 
38. Barrigón Morillas, J.M.; Rey Gozalo, G.; Montes González, D.; Atanasio Moraga, P.; Vílchez-Gómez, R. Noise Pollution and Urban Planning. Curr. Pollut. Rep. 2018, 4, 208-219. [CrossRef]

39. Prieto Gajardo, C.; Barrigón Morillas, J.M.; Rey Gozalo, G.; Vílchez-Gómez, R. Can weekly noise levels of urban road traffic, as predominant noise source, estimate annual ones? J. Acoust. Soc. Am. 2016, 140, 3702-3709. [CrossRef]

40. Morley, D.W.; Gulliver, J. Methods to improve traffic flow and noise exposure estimation on minor roads. Environ. Pollut. 2016, 216, 746-754. [CrossRef]

41. De la Prida, D.; Pedrero, A.; Navacerrada, M.A.; Díaz, C. Relationship between the geometric profile of the city and the subjective perception of urban soundscapes. Appl. Acoust. 2019, 149, 74-84. [CrossRef]

42. Hong, J.Y.; Jeon, J.Y. Relationship between spatiotemporal variability of soundscape and urban morphology in a multifunctional urban area: A case study in Seoul, Korea. Build. Environ. 2017, 126, 382-395. [CrossRef]

43. Barrigón, J.M.; Escobar, V.G.; Gozalo, G.R.; Vílchez-Gómez, R. Possible relation of noise levels in streets to the population of the municipalities in which they are located. J. Acoust. Soc. Am. 2010, 128, EL86-EL92. [CrossRef]

44. Ballesteros, M.J.; Fernández, M.D.; Flindell, I.; Torija, A.J.; Ballesteros, J.A. Estimating leisure noise in Spanish cities. Appl. Acoust. 2014, 86, 17-24. [CrossRef]

45. Chang, T.-Y.; Liang, C.-H.; Wu, C.-F.; Chang, L.-T. Application of land-use regression models to estimate sound pressure levels and frequency components of road traffic noise in Taichung, Taiwan. Environ. Int. 2019, 131, 104959. [CrossRef]

46. Aguilera, I.; Foraster, M.; Basagaña, X.; Corradi, E.; Deltell, A.; Morelli, X.; Phuleria, H.C.; Ragettli, M.S.; Rivera, M.; Thomasson, A.; et al. Application of land use regression modelling to assess the spatial distribution of road traffic noise in three European cities. J. Expo. Sci. Environ. Epid. 2014, 25, 97-105. [CrossRef]

47. Torija, A.J.; Genaro, N.; Ruiz, D.P.; Ramos-Ridao, A.; Zamorano, M.; Requena, I. Priorization of acoustic variables: Environmental decision support for the physical characterization of urban sound environments. Build. Environ. 2010, 45, 1477-1489. [CrossRef]

48. Lee, E.Y.; Jerrett, M.; Ross, Z.; Coogan, P.F.; Seto, E.Y.W. Assessment of traffic-related noise in three cities in the United States. Environ. Res. 2014, 132, 182-189. [CrossRef]

49. Oiamo, T.H.; Davies, H.; Rainham, D.; Rinner, C.; Drew, K.; Sabaliauskas, K.; Macfarlane, R. A combined emission and receptor-based approach to modelling environmental noise in urban environments. Environ. Pollut. 2018, 242, 1387-1394. [CrossRef]

50. Yang, H.; Song, J.; Choi, M. Measuring the Externality Effects of Commercial Land Use on Residential Land Value: A Case Study of Seoul. Sustainability 2016, 8, 432. [CrossRef]

51. Sieber, C.; Ragettli, M.S.; Brink, M.; Toyib, O.; Baatjies, R.; Saucy, A.; Probst-Hensch, N.; Dalvie, M.A.; Röösli, M. Land Use Regression Modeling of Outdoor Noise Exposure in Informal Settlements in Western Cape, South Africa. Int. J. Environ. Res. Public Health 2017, 14, 1262. [CrossRef]

52. Gozalo, G.R.; Morillas, J.M.B.; Escobar, V.G. Analysis of Noise Exposure in Two Small Towns. Acta Acust. United Ac. 2012, 98, 884-893. [CrossRef]

53. Rey Gozalo, G.; Barrigón Morillas, J.M. Analysis of Sampling Methodologies for Noise Pollution Assessment and the Impact on the Population. Int. J. Environ. Res. Publuic Health 2016, 13, 490. [CrossRef] [PubMed]

54. Gómez Escobar, V.; Barrigón Morillas, J.M.; Rey Gozalo, G.; Vílchez-Gómez, R.; Carmona Del Río, J.; Méndez Sierra, J.A. Analysis of the Grid Sampling Method for Noise Mapping. Arch. Acoust. 2012, 37, 499-514. [CrossRef]

55. ISO 1996-2. Description, Measurement and Assessment of Environmental Noise, Part 2: Determination of Environmental Noise Levels; International Organization for Standardization: Geneva, Switzerland, 2017.

56. Kleinbaum, D.G.; Kupper, L.L.; Muller, K.E. Applied Regression Analysis and Other Multivariable Methods; PWS-KENT Publishing Company: Boston, MA, USA, 1988.

57. World Health Organization. Environmental Noise Guidelines for the European Region; World Health Organization, Regional Office for Europe: Copenhagen, Denmark, 2018. Available online: https://www.euro.who. int/en/publications/abstracts/environmental-noise-guidelines-for-the-european-region-2018 (accessed on 14 September 2020).

58. World Health Organization. Guidelines for Community Noise; World Health Organization: Geneva, Switzerland, 1999. Available online: https://apps.who.int/iris/handle/10665/66217 (accessed on 14 September 2020). 
59. Alvarado, R.E.M.; Morillas, J.M.B.; Gozalo, G.R. Urban characteristics and traffic noise in Loja (Ecuador). In Proceedings of the 46th International Congress and Exposition on Noise Control Engineering, INTER-NOISE 2017, Hong Kong, China, 27-30 August 2017.

60. Lu, X.; Kang, J.; Zhu, P.; Cai, J.; Guo, F.; Zhang, Y. Influence of urban road characteristics on traffic noise. Transport. Res. D Transp. Environ. 2019, 75, 136-155. [CrossRef]

61. Rey Gozalo, G.; Barrigón Morillas, J.M.; Trujillo Carmona, J.; Montes González, D.; Atanasio Moraga, P.; Gómez Escobar, V.; Vílchez-Gómez, R.; Méndez Sierra, J.A.; Prieto-Gajardo, C. Study on the relation between urban planning and noise level. Appl. Acoust. 2016, 111, 143-147. [CrossRef]

62. Harouvi, O.; Ben-Elia, E.; Factor, R.; de Hoogh, K.; Kloog, I. Noise estimation model development using high-resolution transportation and land use regression. J. Expo. Sci. Environ. Epid. 2018, 28, 559-567. [CrossRef]

63. Goudreau, S.; Plante, C.; Fournier, M.; Brand, A.; Roche, Y.; Smargiassi, A. Estimation of spatial variations in urban noise levels with a land use regression model. Environ. Pollut. 2014, 3, 48-58. [CrossRef]

64. Ragettli, M.S.; Goudreau, S.; Plante, C.; Fournier, M.; Hatzopoulou, M.; Perron, S.; Smargiassi, A. Statistical modeling of the spatial variability of environmental noise levels in Montreal, Canada, using noise measurements and land use characteristics. J. Expo. Sci. Environ. Epid. 2016, 26, 597-605. [CrossRef]

65. Olayinka, O.S. Effective noise control measures and sustainable development in Nigeria. World J. Environ. Eng. 2013, 1, 5-15.

66. Montes González, D.; Barrigón Morillas, J.M.; Rey Gozalo, G.; Godinho, L. Effect of parking lanes on assessing the impact of road traffic noise on building façades. Environ. Res. 2020, 184, 109299. [CrossRef]

67. Belsley, D.A. Conditioning Diagnostics: Collinearity and Weak Data in Regression; John Wiley \& Sons: Hoboken, NJ, USA, 1991.

68. Licitra, G.; Moro, A.; Teti, L.; Del Pizzo, A.; Bianco, F. Modelling of acoustic ageing of rubberized pavements. Appl. Acoust. 2019, 146, 237-245. [CrossRef]

69. Praticò, F.G. On the dependence of acoustic performance on pavement characteristics. Transp. Res. D Transp Environ. 2014, 29, 79-87. [CrossRef]

70. Praticò, F.G.; Anfosso-Lédée, F. Trends and Issues in Mitigating Traffic Noise through Quiet Pavements. Procedia Soc. Behav. 2012, 53, 203-212. [CrossRef]

71. WG-AEN. Good Practice Guide for Strategic Noise Mapping and the Production of Associated Data on Noise Exposure, version 2; European Commission Working Group-Assessment of Exposure to Noise (WG-AEN): Brussels, Belgium, 2007.

72. Bertellino, F.; Cicoira, P.; Gerola, F.; Clementel, M.; Scaramuzza, P.; Nardelli, M. Noise mapping of agglomerations: A comparision of interim standards vs new CNOSSOS-EU method in a real case study. In Proceedings of the 45th International Congress and Exposition on Noise Control Engineering: Towards a Quieter Future, INTER-NOISE 2016, Hamburg, Germany, 21-24 August 2016; pp. 1356-1366.

Publisher's Note: MDPI stays neutral with regard to jurisdictional claims in published maps and institutional affiliations.

(C) 2020 by the authors. Licensee MDPI, Basel, Switzerland. This article is an open access article distributed under the terms and conditions of the Creative Commons Attribution (CC BY) license (http://creativecommons.org/licenses/by/4.0/). 